Elisabeth Iversen, phd, er universitetslektor i naturfag- og naturbruksdidaktikk ved Norges miljø- og biovitenskapelige universitet, NMBU. Hennes forskningsinteresser er uteundervisning, miljøbevisst medborgerskap, utdanning for bærekraftig utvikling og design-basert forskning.

\title{
Natursti i naturfag på videregående skole: En studie av postene og elevenes erfaringer fra en natursti om radioaktivitet og stråling
}

\begin{abstract}
This article explores how a nature trail can be used as an approach in science education at an uppersecondary level in Norway. The topic of the trail is radioactivity and radiation. The article illuminates obstacles and possibilities connected to the trail's posts, how the students experience the posts, and what takes place during the transport between posts. This inspires how the nature trail can be redesigned. The findings point to that the assignments given in the posts are typically closed questions that to a small degree are related to phenomena at the location. Video observations show that student groups meet each other, and they help each other with the questions. The student group followed in this article, uses approximately half of the time available for walking between posts. This is regarded as unused potential for learning. The redesign is based on didactical reconsiderations consisting of seven questions that can be adapted to other contexts. The contributions of this article are knowledge and experiences concerning a nature trail in science, which is an unexplored area within the field of outdoor education pedagogy.
\end{abstract}

\section{INNLEDNING}

Natursti kan være et interessant virkemiddel i naturfagundervisningen, dersom naturstien og dens poster blir tilfredsstillende utformet. Denne artikkelen utforsker en natursti som ble gjennomført for en naturfagklasse fra en videregående skole. Artikkelen gransker naturstiens poster og hvordan et utvalg av elever erfarer naturstien.

Naturfag er et fellesfag første året på videregående skole i Norge. Den naturstien som utforskes i denne artikkelen er en del av et større undervisningsopplegg om stråling og radioaktivitet. I hovedsak bygger innholdet i dette temaet på fysikk. Tradisjonell fysikk oppfatter ofte kunnskap som noe som overføres, mer enn som noe som læres gjennom aktivitet (Duit, Schecker, Höttecke \& Niedderer, 2014). Det kan være en av årsakene til at det er begrenset med kunnskap om uteundervisning i fysikk. Ayotte-Beaudet, Potvin, Lapierre \& Glackin (2017) fant i deres litteraturgjennomgang om uteundervisning at temaer tilknyttet fysikk sjelden blir undervist ute. 
Natursti er tilsynelatende en læringsaktivitet som lenge har vært brukt i skolen (Myers, 1934, 1930). Likevel synes natursti å ha fătt begrenset oppmerksomhet i forskningen. Litteratursøk utført i databasene Oria, Brage, Eric, Web of Science, Scopus og Diva Portal med (kombinasjoner av) søkeordene uteundervisning, fysikksti og natursti gir få fagfellevurderte artikler. Spesielt når søkene begrenses til faglig innhold (fysikk) returnerer det svært få artikler som omhandler naturstier for elever i ungdomsskole og videregående skole. Dette kan tyde på at natursti som virkemiddel i uteundervisning generelt og med et fysikktema spesielt er et uutforsket område i forskningen.

Natursti brukes ofte i formidling av naturvitenskap, for eksempel gjennom å gjøre deltakerne av stien oppmerksom på det biologiske mangfoldet som er i omgivelsene gjennom oppslag eller oppgaver (Kerry, 1979). Natursti synes å være en populær aktivitet og det er flere aktører i Norge som retter seg mot skolen med forslag til naturstier om naturfaglige temaer for barn og unge (se for eksempel naturfag.no, miljølære.no og norskjegerogfiskeforbund.no). Natursti kan også brukes for å formidle mer abstrakt kunnskap, for eksempel der stien blir en metafor for tiden fra Big Bang og frem til i dag (Lehto m. fl., 2012). Naturstier kan ha noe ulik form og hensikt i skolen, men vanligvis innebærer det at elever skal finne poster langs en sti og gjøre oppgaver på disse postene.

Denne artikkelen utforsker hvordan natursti kan brukes som et virkemiddel i naturfagundervisningen på videregående trinn. Kvaliteten av naturstien baserer seg på analyse av naturstiens poster og elevenes erfaringer med å gjennomføre hele naturstien. Dernest er naturstiens kvaliteter og svakheter et utgangspunkt for diskusjon rundt potensialet for forbedring, et såkalt redesign, av naturstien. Følgende forskningsspørsmål leder artikkelen:

(i) Hvordan er postene i naturstien utformet?

(ii) Hvordan erfarer elevene naturstien?

(iii) Hvordan kan en natursti redesignes for å tilrettelegge for målrettede erfaringer?

\section{UNDERVISNING I NATUREN}

Uteundervisning er et mangefasettert begrep, med ulike definisjoner. I denne artikkelen forstås uteundervisning som en undervisning som finner sted i naturen, i skolens regi og utført av en eller flere faglærere. Dette er i tråd med den skandinaviske forståelsen av uteundervisning (Fägerstam, 2014). Flere hevder at naturen er en autentisk og kontekstuell læringsarena (Ayotte-Beaudet m.fl., 2017; Braund \& Reiss, 2006; Fägerstam, 2014; Glackin, 2016; Remmen \& Frøyland, 2015). Videre viser empiriske studier at naturfagundervisning utendørs kan gi et større læringsutbytte enn undervisning gjennomført i klasserommet (Fägerstam \& Blom, 2013; Orion \& Hofstein, 1994). Av sosiale aspekter viser empiriske studier at lærerens rolle kan oppleves mindre rigid, og at uteundervisning kan bidra til bedre samhold mellom elevene i klassen (Fägerstam, 2014; Remmen \& Frøyland, 2014). I tillegg kan undervisning i nærmiljøet bidra til at elevene opplever tilhørighet, noe som vil være verdifullt for elevenes læring (Iversen \& Jónsdóttir, 2018a).

Ayotte-Beaudet med kolleger (2017) etterspør flere studier om utendørs fysikk. Det foreligger enkelte studier av fysikkundervisning i fornøyelsesparker (blant annet Pendrill, 2013), beskrivelser av fysikkundervisning tilknyttet friluftsområder (Aspinall, 2016) og skolegårder (Popov, 2006). I hovedsak er det faglige innholdet knyttet til bevegelse, krefter og energi.

\section{Natursti som læringsaktivitet i fysikk}

Foster (1989) er en av få som gir beskrivelser av en natursti i fysikk. En av Fosters (1989) viktigste anbefalinger er at postene plasseres i fysisk nærhet av det naturfenomenet som skal undersøkes. Videre uttrykker Foster (1989) at naturstier har potensial for å gjøre elever oppmerksomme på fysikk og teknologi som omgir dem i hverdagen. Det argumenteres med at elevene blir mer engasjerte og får muligheter til å koble fysikk til virkeligheten. Det er en urban sti Foster (1989) viser til. Han gir forslag til ulike temaer som kan undersøkes, hvilke oppgaver elevene kan få på posten og hvilket utstyr som er nødvendig å ha tilgjengelig. Foster (1989) sine eksempler på oppgaver er i stor grad kontekstavhen- 
gige. For eksempel skal elevene gjøre målinger med geigerteller av granittstein. Samtidig gir han eksempler på oppgaver som elevene like gjerne kan løse i klasserommet, som å nevne en planet som har drivhuseffekt. Han gir også noen faglige tips og forklaringer som lærere bør tenke på før de skal ta elever med ut, samt at han gir forslag til oppfølgingsspørsmål.

I en rapport av Spangler (2004) beskrives en natursti med utforskende aktiviteter i fysikk sammen med geofag, biologi, teknologi og kulturhistorie. Aktivitetene forankres til lokale forhold. I likhet med Foster (1989), argumenterer Spangler (2004) at utendørsfysikk bidrar til faglig engasjement. Både Fosters (1989) og Spanglers (2004) bidrag er beskrivende og i mindre grad inngående analyse og refleksjon av natursti i fysikkrelaterte temaer.

\section{Erfaring og læring i naturen}

I denne artikkelen forstås læring i uterommet som erfaringer som kan være gode eller mindre gode i utdanningsøyemed. John Dewey er talsperson for aktiv og erfaringsorientert læring. For å være gode erfaringer må de være målrettede (Dewey, 1938/1991). Erfaringene bør peke i en retning, for eksempel opp mot læringsmål. Videre bør ikke kropp og sinn sees på som dualistiske enheter, men noe som er avhengig av hverandre (Dewey, 1938/1991). Derfor skal ikke erfaringen kun strebe etter å nå kognitive mål, men inneha et bredere perspektiv på læring. Både kropp og sinn skal være involvert i læringsprosessene. Samtidig kan det være utfordrende å måle en mer kroppsliggjort og erfaringsorientert læring (DeWitt \& Storksdieck, 2015). En måte å vurdere elevenes erfaringer i uterommet på er gjennom fem læringsaspekter inspirert av blant annet Mogk \& Goodwin (2012). Disse beskrives som: (i) kognitive aspekter, (ii) affektive aspekter (iii) sosiale aspekter (iv) fysiske og ferdighetsmessige aspekter og (v) metakognitive aspekter. Ifølge Mogk og Goodwin (2012) skal aspektene ikke forstås som atskilte skott, men som noe som er vevet sammen og påvirker hverandre.

Disse aspektene er benyttet i sentral litteratur om læring utendørs. For eksempel har kognitive, affektive og sosiale aspekter i læringsprosessen blitt undersøkt av flere (DeWitt \& Storksdieck, 2015; Kent, Gilbertson \& Hunt, 1997; Orion \& Hofstein, 1994). En svensk empirisk studie (Wilhelmsson, Ottander \& Lidestav, 2012) har utforsket naturen som arena for at elevene kan øve fysiske og ferdighetsmessige aspekter, i tillegg til de overnevnte aspektene. Rickinson og kollegers (2004) sin anerkjente litteraturgjennomgang konkluderer med at alle disse aspektene kan øves ved uteundervisning, dersom uteundervisningen er tilfredsstillende gjennomført. Tilsynelatende er det få studier som utforsker metakognitive aspekter i uterommet. Ifølge Mogk \& Goodwin (2012) vil øving av metakognitive aspekter være nyttig, siden elevene bør være bevisst på at læringssituasjonen er en annen enn ved undervisning i klasserommet.

Det kan være visse likheter mellom læringssituasjoner i natursti og i et vitensenter eller museum. I vitensentre vil det også være en mer kroppsliggjort tilnærming til læring, undervisningen vil være styrt av elevene selv og ofte vil elevene arbeide sammen i mindre grupper (Stuedahl, 2017). I tillegg kan elevene gå bestemte løyper og utføre handlinger instruert av installasjoner eller arbeidsark. Det vil derfor være visse likheter mellom oppgavene formulert på arbeidsark som elever bruker ved vitensentre og museum og postene i en natursti.

\section{Metode}

\section{Design-basert forskning}

Design-basert forskning (DBR) er en praksisnær tilnærming til forskning som bidrar med å bygge bro mellom teorier generert fra forskning og utdanningspraksiser (Anderson \& Shattuck, 2012; DesingBased Research Collective, 2006). Siden DBR tillater en viss fleksibilitet i utførelsen er det ulike fremgangsmåter (Barab \& Squire, 2004; Design-Based Research Collective, 2006; Wang \& Hannafin, 2005), slik som design research (Reeves, Herrington \& Oliver, 2005), design experiments (Collins, Joseph \& Bielaczyc, 2004) og design-basert forskning (Juuti \& Lavonen, 2006). Jeg er inspirert av Wang og Hannafins (2005, 6-7) definisjon av DBR: 
a systematic but flexible methodology aimed to improve educational practices through iterative analysis, design, development, and implementation, based on collaboration among researchers and practitioners in real-world settings, and leading to contextually-sensitive design principles and theories.

Definisjonen bidrar med retningslinjer for mål (forbedre utdanningspraksiser) og hvordan gjennomføre DBR-studier (iterative analyser, design, utvikling og implementering basert på samarbeid). Videre sier definisjonen noe om hvem som er involvert (forskere og lærere/praksisutøvere), hvor (i den settingen hvor læringen foregår) og ønsket utfall (kontekst-sensitive designprinsipper og teorier).

Basert på denne tolkningen av Wang og Hannafins (2005) definisjon, deler jeg prosessen inn i fem faser: 1) utvikling av et design, 2) utprøving, 3) analyse og refleksjon, 4) videre utvikling av designet eller et såkalt redesign og 5) ny implementering. Artikkelen vektlegger spesielt fasene 2-4 ved å analysere og reflektere rundt selve utprøvingen av naturstien og redesignprosessen. Designet redesignes når det er behov for forbedring og fornying, og styres både av empiri og litteratur (Plomp, 2013). Redesignet i denne artikkelen bidrar med mer overordnede didaktiske avveininger enn endringer av den konkrete naturstien. På denne måten kan redesignet overføres og tilpasses andre kontekster. Svakheten med designet er at utvikling av naturstien i liten grad er basert på litteratur. Det kan forklares med at det foreligger begrenset med konkret kunnskap om naturstier. I tillegg ble naturstien ansett som en sideaktivitet av meg og de to lærerne som planla naturstien. Naturstiens hovedhensikt var å halvere klassen slik at resterende halvdel kunne følge andre aktiviteter i dette opplegget om stråling og radioaktivitet. Det forventes derfor et betydelig redesign.

Naturstien bør ikke stå alene i redesignsprosessen uten å bli satt i sammenheng med et for- og etterarbeid. Forskning peker på at vektlegging av for- og etterarbeid er sentralt for elevenes utbytte av uteundervisningen (Dhanapal \& Lim, 2013; Remmen \& Frøyland, 2015). Uteundervisning skal støtte oppunder klasseromsundervisning og dens læringsmål (Braund \& Reiss, 2006; Öhman \& Sandell, 2016). Derfor vil redesignet av naturstien bli satt i kontekst med et for- og etterarbeid der det er hensiktsmessig.

\section{Datamateriale}

Datamaterialet er delt inn i to hoveddeler. Den første delen av materialet ble generert ved at en elev, Simen, går naturstien med hodekamera. Simen er på gruppe med Jannike og Elsa. Denne videoen, som er totalt 45 minutter, benyttes for å kunne si noe om elevenes erfaringer. Videoen viser et utsnitt av hva elevene gjør, hva de samtaler om og hvem de møter i naturstien. For å få en fyldigere beskrivelse av kontekst, har jeg også lent meg til feltnotater, lydopptak av hele klassen ved start og slutt av naturstien, samt etterarbeid på skolen uka etter. Materialet er samlet og transkribert av forfatter.

Som forsker hadde jeg liten mulighet til detaljert direkte observasjon av elevene under naturstien. Bruk av hodekamera er en gunstig metode for indirekte observasjon av uteundervisning (Frøyland, Remmen, Mork, Ødegaard \& Christiansen, 2015). Begrensninger med bruk av hodekamera i dette tilfellet er at filmen viser hva eleven er interessert i, og ikke nødvendigvis hva forsker ville ha vektlagt. En av fordelene med video er at det muliggjør repetitive observasjoner slik at sekvenser kan utforskes i detalj (Tiberghien \& Sensevy, 2012).

Transkripsjonene etterstreber å gjengi ordrett utsagn. Det er enkelte utfordringer tilknyttet transkribering, da samtalene foregår ute. Uklarheter blir markert med [uklart] i transkripsjonene.

Postene, inkludert deres plassering og innhold, danner den andre hoveddelen av det empiriske materialet.

Studien er godkjent av NSD. Alle navnene er pseudonymer for å sikre anonymitet. 


\section{Dataanalyser}

Som beskrevet over, har jeg delt det empiriske materialet i to deler: postene og videoobservasjoner fra hodekamera. I analysene baserer jeg meg på to sett av verktøy for analyse for å undersøke kvaliteten til postene og elevenes erfaringer med naturstien.

\section{Analyse av naturstiens poster}

På grunn av at det er tilsynelatende lite kunnskap om natursti, benyttes det litteratur om læring i en museumskontekst. Hensikten med analysen er å vurdere postenes kvalitet. Motivet til postene er å bidra til målrettede erfaringer hos elevene. Forskning fra en museumskontekst viser at godt utformede arbeidsark er fordelaktig for læring (Mortensen \& Smart, 2007). Ved å analysere ulike arbeidsark benyttet i museum, utformet James Kisiel (2003) karakteristikker for arbeidsark som påvirker elevenes læring. Disse vil jeg gjengi, for så å beskrive hvordan jeg forstår og tilpasser karakteristikkene som analyseverktøy for en natursti. Karakteristikkene er: arbeidsarkets mengde, orienteringsmarkører, stedsspesifikke oppgaver, informasjonskilder, frihetsgrader, kognitivt nivå og til slutt svarets format. Jeg tilnærmer meg postene i naturstien ut ifra følgende karakteristikker:

(i) Postens mengde forstås som mengde arbeid elevene skal gjøre på postene. Graderes lav, middels og høy.

(ii) Postens plassering forstås som i hvilken grad oppgavene på postene er avhengig av stedet posten er hengt opp. Graderes lav, middels og høy.

(iii) Informasjonskilde forstås som hvilken kilde elevene skal hente informasjon fra. Kategoriseres som tekst (fra posten), objekt(er) i naturen, gruppas egen kunnskap.

(iv) Frihetsgrad forstås som i hvilken grad elevene kan gjøre valg på postene. Dette graderes med lav frihetsgrad med lukkede spørsmål med ett svar, til middels frihetsgrad som er et halv-åpent spørsmål med rom til flere ulike svar og høy frihetsgrad hvor svaret er helt åpent og elevene velger selv hvordan de skal løse oppgaven.

(v) Svarets format forstås som i hvilket format elevene skal svare på oppgaven (skriftlig, verbalt, video).

(vi) Annet

To karakteristikker fra Kisiel (2003) er ikke tatt hensyn til. Jeg har valgt å ekskludere orienteringsmarkører da dette blir omtalt som navigasjon senere, og kognitivt nivå anses mer relevant å diskutere rundt elevenes erfaringer med å gå naturstien. Kisiels karakteristikk om stedsspesifikke oppgaver, er nå navngitt som 'postens plassering' slik at den er tilpasset naturstikonteksten. Jeg har valgt å inkludere karakteristikken 'Annet' slik at det kan være rom for å ta hensyn til elementer i postene som Kisiels (2003) karakteristikker ikke fanger opp.

\section{Analyse av elevenes erfaringer med å gå naturstien}

Videofilmen ble delt i inn i de to hovedaktivitetene post og gå-etappe mellom postene. Til sammen var det ti sekvenser som ble sett i lys av de fem læringsaspektene beskrevet tidligere. Læringsaspektene ble forstått slik:

(i) kognitive aspekter forstås som anvendelse av naturfaglig innhold.

(ii) affektive aspekter forstås som elevenes egne uttrykte følelser som glede og frustrasjon til det naturfaglige temaet

(iii) sosiale aspekter forstås som elev-elev interaksjon og spesielt samarbeid mellom elevene i naturstien.

(iv) fysiske og ferdighetsmessige aspekter forstås som en utvikling av ferdigheter både tilknyttet faget og mer generelle ferdigheter som navigering

(v) metakognitive aspekter i form av at den lærende blir bevisst på egne læringsprosesser. 
Fysiske og ferdighetsmessige aspekter er vanskelig å overføre fra videoformat til transkripsjon annet enn ved beskrivelser og bilder. Derfor har jeg valgt å beskrive og analysere et stillbilde fra videoen i funnkapitlet. Postenes utforming vil ha påvirkning på elevenes erfaringer. Til sammen gir disse to settene av analyseverktøy en tilfredsstillende indikasjon på kvaliteten av postene og elevenes gjennomføring av naturstien.

\section{Empirisk kontekst}

Jeg velger å gi en kort beskrivelse av den empiriske konteksten inkludert naturstiens forarbeid og etterarbeid. I tillegg gis en beskrivelse av naturområdet ansett som relevant for artikkelen.

For hele uteundervisningsøkta, inkludert dens forarbeid og etterarbeid, ble det utformet to læringsmål: Elevene i klassen skal gjennom ulike aktiviteter få en grunnleggende forståelse av hva begrepet 'stråling' innebærer og elevene skal ha hørt om ulike begreper knyttet til de ulike radioaktive strålingstypene. Forarbeidet, gjennomført i samme økt som gjennomføringen av naturstien, var første time knyttet til hovedområde stråling og radioaktivitet. Derfor er det tillagt et lavt faglig nivå. Forarbeidet varte i ca. 30 minutter. Læreren spilte blant annet av en kort film som håndterte muligheter og utfordringer med å bygge kjernekraftverk i Norge. Elevene fikk vite at de skulle filme på en av postene.

Gjennomføringen fant sted i et skogholt og det var tre skoletimer til disposisjon for uteundervisningen. Denne dagen var det regn i luften. En base var start- og sluttpunktet til naturstien. I basen var den andre gruppen med lærer. Naturstien hadde en lineær form i en barskog i en jordbrukskommune på Østlandet.

Postene var satt ut slik at de kunne ses fra en sti som elevene skulle følge i nærheten av skolen. Naturstien bestod av fem poster hvor fire poster er tilknyttet radioaktivitet og stråling, mens en post er tilknyttet biologi (Tabell 1). Elevene hadde 45 min tilgjengelig til å gå naturstien.

Tabell 1: En oversikt over tematisk innhold i postene.

\begin{tabular}{|l|l|l|l|l|l|}
\hline & Post 1 & Post 2 & Post 3 & Post 4 & Post 5 \\
\hline $\begin{array}{l}\text { Oppgavene } \\
\text { er knyttet } \\
\text { til: }\end{array}$ & $\begin{array}{l}\text { Alfa-beta } \\
\text { og gamma- } \\
\text { stråling }\end{array}$ & $\begin{array}{l}\text { Marie Curie og } \\
\text { radioaktivitet }\end{array}$ & $\begin{array}{l}\text { Kjernekraftverk } \\
\text { (filme et inn- } \\
\text { slag) }\end{array}$ & $\begin{array}{l}\text { Økologisk } \\
\text { påvirkning på } \\
\text { reinsdyr etter } \\
\text { Tsjernobylulykka }\end{array}$ & $\begin{array}{l}\text { Repetisjons- } \\
\text { spørsmål fra } \\
\text { humanbiologi og } \\
\varnothing \text { kologi }\end{array}$ \\
\hline
\end{tabular}

Etterarbeidet fant sted inne på skolen ei uke etter uteundervisningen. I etterarbeidet ble elevene delt inn i syv ulike grupper, hvor en av gruppene skulle lage en paneldebatt som diskuterte kjernekraftverk i Norge. Filmen en av gruppene hadde laget i naturstien ble brukt som et innslag under paneldebatten.

\section{FUNN}

Med utgangspunkt i de to første forskningsspørsmålene presentert innledningsvis, vil jeg først svare på hvordan postene er utformet og deretter hvordan elevene erfarer naturstien. 


\section{Postenes utforming}

Postene som helhet har relativt liten variasjon med tanke på hvordan de er utformet (Tabell 2). Oppgavene er stort sett lukkede og det forventes et tekstlig svar. Postene i denne naturstien tar ikke utgangspunkt i den lokale naturen, det kontekstnære, og de stimulerer i liten grad til elevaktivitet og utforskning. Videre forventes det i liten grad at elevene viser at de gjør logiske resonnementer for å løse oppgaven. For eksempel blir elevene i Post 1 bedt om å svare på hvilken stråling som er farligst når den er inne i kroppen, men de blir ikke eksplisitt bedt om å grunngi svaret sitt. Postenes mengde er derimot ulike. Enkelte av postene har mange spørsmål (spesielt Post 5), andre har mye tekst (spesielt Post 4), mens noen krever filming (Post 3) og andre har kun to spørsmål som krever relativt enkle svar. For eksempel blir elevene spurt om de kan nevne minst tre radioaktive grunnstoffer på Post 2.

Tabell 2: Analyse av postene inspirert av kategoriene fra Kisiel (2003).

\begin{tabular}{|l|l|l|l|l|l|l|}
\hline & $\begin{array}{l}\text { Postens } \\
\text { mengde }\end{array}$ & $\begin{array}{l}\text { Postens } \\
\text { plassering }\end{array}$ & $\begin{array}{l}\text { Informasjons- } \\
\text { kilde }\end{array}$ & Frihetsgrader & Svarets format & Annet \\
\hline $\begin{array}{l}\text { Pospm } 1 \\
\text { Lite tekst }\end{array}$ & Middels & Lav & Kunnskap & Lav & Tekst & $\begin{array}{l}\text { Farer med } \\
\text { radioaktivitet }\end{array}$ \\
\hline Post 2 & $\begin{array}{l}\text { Lav } \\
2 \text { spm } \\
\text { Noe tekst }\end{array}$ & Lav & Kunnskap & $\begin{array}{l}\text { Spm 1 Lav } \\
\text { Spm 2 Middels }\end{array}$ & Tekst & - \\
\hline Post 3 & $\begin{array}{l}\text { Høy } \\
\text { spm } \\
\text { Noe tekst }\end{array}$ & Lav & $\begin{array}{l}\text { Kunnskap } \\
\text { Diskusjon }\end{array}$ & $\begin{array}{l}\text { Spm 1-2 Lav } \\
\text { Spm 3 Høy }\end{array}$ & Tekst og video & $\begin{array}{l}\text { Spm 3 er en } \\
\text { kontrovers. }\end{array}$ \\
\hline Post 4 & $\begin{array}{l}\text { Middels } \\
\text { 2 spm } \\
\text { Mye tekst }\end{array}$ & Lav & Kunnskap & $\begin{array}{l}\text { Spm 1 Middels } \\
\text { Spm 2 Lav }\end{array}$ & Tekst & $\begin{array}{l}\text { Farer med } \\
\text { radioaktivitet }\end{array}$ \\
\hline Post 5 & $\begin{array}{l}\text { Høy } \\
11 \text { spm }\end{array}$ & Lav & Kunnskap & Spm 1-11 Lav & Tekst & $\begin{array}{l}\text { Repetisjon/ } \\
\text { annet tema }\end{array}$ \\
\hline
\end{tabular}

Post 3 skiller seg noe ut fra de andre postene fordi elevene skal arbeide med en kontrovers hvor det ikke er et klart fasitsvar. De skal argumentere for om de er for eller imot kjernekraftverk, som en forlengelse av filmen fra forarbeidet. I posten står det at elevene kan velge selv hvilken side av saken de vil argumentere for. En annen ting som gjør denne posten unik er svarets format. Her skal svaret og argumentasjonen filmes med mobiltelefon. Videofilmen skulle igjen brukes i etterarbeidet, dog ble ikke dette tydeliggjort for elevene på selve posten.

Post 5 har et annet tema hvor spørsmålene er knyttet til biologi. Posten har mange spørsmål og det etterspørres spesielt definisjoner på ulike begreper eller prosesser. For eksempel 'hva heter den siste fasen i suksesjonsprosessen?' Post 5 er ikke satt opp på et sted som er i denne siste fasen av suksesjon. Dette kunne ha hevet graderingen av postens plassering. Post 4 er et forsøk på å overlappe økologi og radioaktivitet ved å vektlegge reinsdyr som beiter sopp som tar opp Cesium-137. 
Postene 1, 3 og 4 ser i stor grad ut til å vektlegge farer ved radioaktivitet. Post 1 relaterer alfa, beta og gammastråling til menneskekroppen, post 3 bruker Tsjernobylulykka som eksempel på katastrofe, mens post 4 ser på Cesium-137-nivået i reinsdyr i Norge 30 år etter Tsjernobylulykka.

På bakgrunn av analysen ville postene ha vært tjent med en noe mer lik arbeidsmengde per post, postenes plassering burde ha vært relevant for oppgavene elevene skulle løse og det burde ha vært mer variasjon i informasjonskilde, frihetsgrader og svarets format.

\section{Innblikk i elevenes erfaringer av naturstien}

I dette delkapitlet rettes søkelyset først mot hvordan elevene erfarer de ulike postene og deretter hva som foregår når elevene går mellom postene.

\section{Elevene på post}

Det er stor variasjon i hvor lang tid elevgruppen bruker på hver post, fordi hver post varierer såpass i arbeidsmengde. På det meste bruker elevene syv minutter (Post 3), mens på post 2 bruker de kun ett minutt. I dette kapitlet belyses elevenes erfaringer med post 3, 4 og 1.

Fra analysene av postene vises det at post 3 skiller seg noe ut fra de andre postene fordi elevene på oppgave 3 blir bedt om å argumentere for eller imot kjernekraftverk og filme dette. Elevene bruker imidlertid mer tid på å bestemme seg for hvem som skal bli filmet, enn om de enten skal være for eller imot kjernekraftverk i Norge. Jannike og Elsa snakker om hva de skal si, hvem som skal filme og hvem som skal snakke. De overtaler Simen til å bli filmet.

Elsa: Er du klar? Klar ferdig gå.

Simen: Du må si hva jeg skal si.

Jannike: Om du er for eller mot kjernekraft.

Simen: Vet ikke jeg noe om.

Jannike: Bare lat som.

Simen: Jammen vi har ikke bestemt oss for om vi er for eller imot.

Jannike og Elsa i kor: Ja, men bare gjør det!

Elsa: Vi må bli ferdig. Bare gjør det, nå kommer det sykt mange folk hit! Vær imot.

Jeg anser det som positivt at elevene får øve sosiale aspekter ved å fordele ulike roller for å løse oppgaven (en skal filme og en skal snakke). Videre aktiviseres elevene ved at svarets format er et produkt (video) og de øver ferdighetsmessige aspekter. Det er også positivt at denne posten bygger videre på videoklippet elevene så i forarbeidet med tanke på å øve kognitive aspekter. Dette kan være en styrke i forbindelse med at elevene har fått mulighet til å gjøre seg kjent med hvilke argumenter som kan brukes for og imot kjernekraftverk i Norge. Samtidig bruker elevene lang tid på å bestemme seg for hvem som skulle filme og hvem som skulle bli filmet. Elevene kunne trolig ha hatt behov for støtte, slik at tiden heller hadde blitt brukt til å diskutere den faglige kontroversen. Videre uttrykkes det at de vil bli ferdige med posten, trolig på grunn av at flere grupper nå står og venter. Post 3 hadde således det beste potensialet for å øve både kognitive, affektive, sosiale og ferdighetsmessige læringsaspekter. Trolig på grunn av manglende støttestruktur for hvordan elevene skal gjennomføre oppgaven ble ikke potensialet utnyttet.

Oppgave 1 fra samme post (Post 3) er et lukket spørsmål og etterspør hvilken ulykke som fant sted i 1986. Fordi elevene i denne gruppa ikke vet svaret, velger Simen å henvende seg til en annen gruppe som ankommer posten:

Simen: Hvilken ulykke er det snakk om?

Jannike: Aner ikke

Simen: Er det den i Japan eller?

Jannike og Elsa mumler: [uklart]. 
[Simen ser seg rundt].

Simen: Sikkert den i Japan, ikke den Hiroshima.

Elsa: Nagasaki.

Simen: Nei ikke den.

[En annen gruppe kommer]

Simen: De kan sikkert hjelpe oss!

Simen [Han henvender seg mot den nye gruppa]: Vent, fordi vi er på filmeposten. Forresten

hvilken ulykke var det som skjedde i 1986?

[To fra den andre gruppa svarer Tsjernobyl i kor.]

Jannike: Hvordan skriver man det?

[Elevene blir enige om hvordan det staves. Ei av jentene fra den andre gruppa sier:]

Hanna: Det er [et] russisk [navn] da vettu.

Simen: Det var russisk. Trudde det var japansk jeg.

Hanna: Hiroshima og Nagasaki er japansk. Det var bomber fra Amerika.

Den andre gruppa hjelper vår gruppe med misoppfatningen om at ulykka fant sted i Japan og ikke Russland (daværende Sovjetunionen), samt hvordan Tsjernobyl staves. Elevene synes å øve sosiale aspekter knyttet til et faglig innhold på tvers av gruppene. Ingen av elevene uttrykker noe som kan tolkes i det affektive aspektet, noe som kanskje kunne ha vært forventet siden 'ulykke' nevnes i oppgaven.

Post 4 inneholder mye tekst som de leser opp. Elevene finner spørsmålene hvor det spørres etter begrepsforklaringer av bequerel og halveringstid. Elsa sier: 'Så skriver du [Jannike] bare bequerel er lik, og halveringstid er lik, og så går vi videre. Så lar vi det bare stå åpent.' Gruppa snakker kort frem og tilbake om svaret, men bestemmer seg for å ta bilde av posten med mobiltelefonen og svare på spørsmålene senere. Spørsmålets formulering er slik at elever vil ha problemer med å svare fordi de ikke har noen annen informasjonskilde enn deres egen kunnskap. I tillegg er dette også begreper som ikke har vært gjennomgått i forarbeidet til naturstien. Derfor kan det være en strategi at elevene venter med å svare på spørsmålene til de er tilbake på skolen, og dermed øver de i liten grad noen av de fem læringsaspektene.

Ved post 1, som omhandler alfa, beta og gammastråling, møter vår gruppe igjen en annen gruppe. Dette utdraget er valgt ut fordi det viser hvordan en annen gruppe samarbeider og arbeider med oppgavene. Simen går til to av guttene, mens Jannike og Elsa går til den ene jenta i denne gruppen og er utenfor hørevidde. Simen møter Jakob og Daniel, som begge bruker mobiltelefonen som informasjonskilde. Jakob holder en humoristisk tone og inviterer Simen inn i samtalen ved å spørre ham:

Jakob: Beta har størst gjennomtrengningsevne, du veit det, ikke sant? Beta!

Simen: Sikkert.

[Jakob og Daniel undersøker på telefonene sine.]

Daniel: Beta har litt større rekkevidde.

Jakob: Større gjennomtrengningsvidde, ikke sant?

Daniel: Den kan bryte gjennom klær, huden. [Leser opp noe fra telefonen, uklart]. (...) Det er jo gamma som er verst holdt jeg på å si. Den kan gå igjennom [kort pause] jævla lang rekkevidde da. Egentlig lengre rekkevidde enn alfa og beta.

Jakob. Men den er kanskje ikke sterkest? Det er alfaen som er størst, men gjennomtrengningsevne...

Daniel: Nei, alfaen blir stoppa av papir.

Jakob: Jaja, men det er det som har størst gjennomtrengningsevne, den er størst, men ikke størst gjennomtrengningsevne.

Simen: Jeg tror kanskje gamma er verst alt i alt, jeg.

Jakob: Hva var oppgave b?

Jakob: Hvilken strålingskilde er farligst når strålingskilden er utenfor kroppen vår? Det er vel den som har best gjennomtrengningsevne. 
Daniel: Men de sa det var utenfor kroppen vår.

Jakob: Ja, da trenger den seg i kroppen.

Daniel: Ja, da er det gamma (noterer).

Jakob: Ja.

Simen: Nå begynner det å regne.

Daniel: Kan du lese neste oppgave, vær så snill?

Jakob: Hva slags stråling er farligst når strålingskilden er inne i kroppen vår?

Daniel: Ja, men nettopp

Jakob: Da er det alfa.

Daniel: Ja, men det betyr at da er det alfa.

I motsetning til Simen sin gruppe, så benytter den andre gruppa mobiltelefon for å finne informasjon om ulike radioaktive strålingstyper. Ved hjelp av mobiltelefonen som informasjonskilde, resonnerer Jakob og Daniel seg frem til at gammastråling er 'farligst' utenfor kroppen, mens alfastråling er 'farligst' hvis det kommer inn i kroppen. De bruker ord som gjennomtrengningsevne, rekkevidde og gjennomtrengningsvidde for å si noe om hva stråling kan gå igjennom. De bruker ord som størst for å beskrive alfa(partikkel) og sterkest for å si noe om potensiell skade stråling kan forvolde. Selv om begrepsbruken er noe upresis, ser det ut til at de forstår hverandre godt og synes å øve kognitive og sosiale aspekter. Selv om Simen i liten grad uttrykker seg i dette utdraget synes han å følge samtalen. Det kan spekuleres i om Simen føler seg mer inkludert av Jakob og Daniel, enn av Elsa og Jannike.

Av utdragene over er det lite som tilsier at elevene er ute. Simens kommentar om at det begynner å regne er derimot en indikasjon på at elevene befinner seg ute.

Jeg har inkludert et stillbilde fra siste utdrag som viser regndråper, skogen og elevene. Bildet synes å vise at elevene øver noe fysiske og sosiale aspekter. De står oppreist, og videoen viser at de beveger seg slik at de kan se på hverandres telefoner. Å stå oppreist og se på hverandres skjermer kan også gjøres i klasserommet. Sammenlignet med klasserommet hvor elevene sitter på stolen sin bak en pult, vil en natursti i større grad tilrettelegge for bevegelse mens de løser oppgaver.

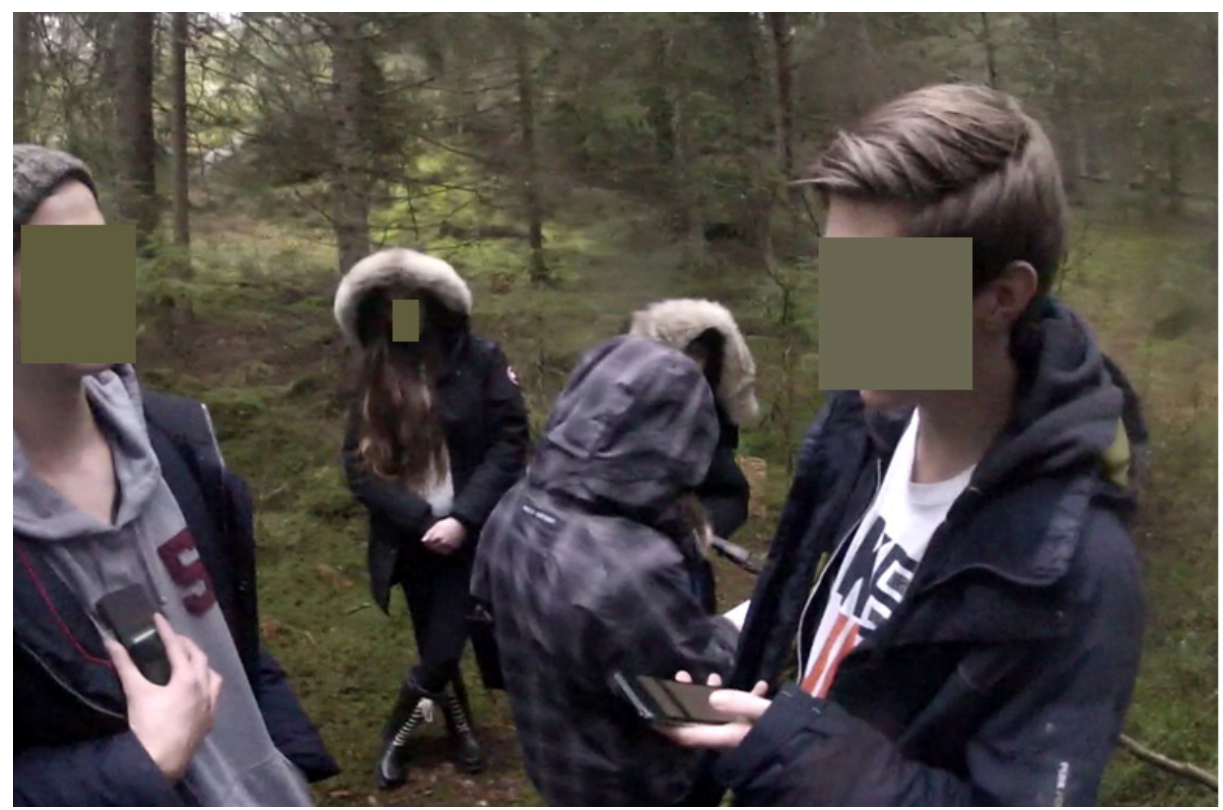

Bilde 1: Bildet viser Jakob og Daniel som bruker mobiltelefonene sine som informasjonskilde. Jannike og Elsa holder posten og står sammen med ei jente fra den andre gruppa. 


\section{Elevene går mellom postene}

Naturstien har en lineær form og gjør at elevene må gå samme vei frem og tilbake. Dette bidrar til at de ulike gruppene møter hverandre. Møtene finner sted både når elevene går mellom postene eller venter på tur (unntaket er det ene tilfellet hvor Simen går til Jakob og Daniel på posten). Gruppa vår møter andre grupper i syv tilfeller. I fem av disse møtene snakker elevene om oppgavene fra naturstien. I fire av disse fem tilfellene får vår gruppe hjelp av de andre, mens i det siste tilfellet er det en annen gruppe som spør om svar fra vår gruppe. I de to siste tilfellene hilser kun elevene på hverandre. At elevene møter hverandre er interessant fordi det tilrettelegger for samarbeid på tvers av gruppene ved at elevene hjelper hverandre med svarene.

Videoen viser at når elevene går, så går de hovedsakelig på rekke fordi deler av stien er smal. De to jentene går ofte tett sammen, mens Simen går ofte for seg selv litt bak jentene, noe som også kan gi indikasjoner på at samarbeidet i gruppa ikke er gunstig. Det at elevene går på rekke, kan begrense elevenes muligheter til å snakke fag sammen innad i gruppa mens de går.

Omtrent halvparten av tiden i naturstien bruker elevene til å gå. Jannike og Elsa opplever dette som bortkastet tid.

Elsa: Det er lissom, tenk så mye vi kunne ha lest da.

Jannike: Vi bruker så jævlig mye tid på å gå.

Elsa: Jeg vet, tenk hvor mye vi kunne ha lest på denne tiden. Gå kunne vi ha gjort på fritiden.

Elsa og Jannike er tydelig frustrerte fordi naturstien ikke bidrar til gode erfaringer. Selv om dette kan knyttes til øving av affektive og metakognitive aspekter, er det ønskelig at det elevene uttrykker også har faglig utbytte. Denne naturstien synes ikke å bidra til et godt utbytte. Noe av grunnen til det kan være knyttet til at temaet er vanskelig å koble til skogen de er i. Etter å ha vært på post 2 om Marie Curie diskuterer elevene hensikten med å være ute i dette temaet:

Jannike: Jeg trudde vi skulle være ute i naturen for å lære om naturen. Ikke for å lære et tema som ikke har noe med naturen [å gjøre] i naturen! (...)

Elsa: Hvis vi først hadde hatt om skog og sånn.

Jannike: Ja ikke sant, det er jo noe annet. Hvis vi hadde lært noe om skogen.

Elsa: Ja

Jannike: Stråling har faen ikke noe med det her å gjøre.

Elsa: I så fall burde vi hatt dette sånn på slutten. Ikke mista kunnskapen med å gjøre det.

Jannike og Elsa synes å øve metakognitive aspekter da de uttrykker en bevissthet om hvordan de ikke lærer. Elsa rapporterer at det ville ha vært mer relevant dersom temaet hadde vært om 'skog og sånn'. Dette kan vise til at de har en oppfatning av at det bør være et tema knyttet til biologi/økologi når de først skal ha uteundervisning i naturfag.

$\AA$ navigere og orientere seg ute vil være ferdighetsmessige aspekter som øves i gå-etappene i en natursti. Elevene har ikke fătt utdelt kart, men de har fått muntlig beskjed om hvor postene ligger både som en del av forarbeidet og i basen. Naturstiens poster inneholder heller ikke orienteringsmarkører, som er en av Kisiels (2003) karakteristikker. I videoen er det tydelig at elevene diskuterer navigering ved flere tilfeller. I et tilfelle går gruppa forbi en post og må snu, noe som skaper frustrasjon. Navigering i skog med få kjennetegn i terrenget, kan gjøre det vanskelig for elevene å finne frem til postene, selv om de var lett synlige fra stien. Regnværet kan ha spilt en rolle, da elevene var mindre opptatt av å se seg rundt og flere av elevene gikk med hetter.

Vår gruppe bruker 43.5 minutter på hele naturstien hvor det var satt av 45 minutter. Denne tiden inkluderer at elevene brukte noe tid på å gå feil. Tiden vil påvirkes av avstanden mellom postene og mengden i postene. Lengden på hele løypa ble ikke registrert i felt. Ved beregninger på kart gjort i etterkant estimeres det at naturstien er ca. 320-350 m i lengde tur/retur. 
Analysene av postene og elevenes erfaringer viser at naturstien ikke var tilfredsstillende utformet som en læringsaktivitet i uterommet slik at elevene blant annet kunne nå de to læringsmålene presentert tidligere. Likevel viste analysene at naturstien bidro til å øve alle fem læringsaspektene, dog er det et større potensial for mer målrettede erfaringer ved bruk av natursti. I neste kapittel utforskes det hvordan en natursti og dens poster kan utformes for å være en nyttig læringsaktivitet $i$ naturfag.

\section{REDESIGN AV NATURSTIEN}

I dette kapitlet har jeg valgt en tilnærming hvor didaktiske overveielser svarer på hvordan naturstien kan redesignes for å tilrettelegge for målrettede erfaringer. Jeg har valgt å ta utgangspunkt i syv spørsmål for videre drøfting av naturstien. Spørsmålene er inspirert av litteratur og analyse fra naturstien presentert tidligere. De syv spørsmålene består av tre åpne spørsmål og fire graderingsspørsmål:

1) Hvordan er postens naturfaglige innhold knyttet til omgivelsene?

2) Hvordan bindes oppgavene i postene til et for- og etterarbeid?

3) Hvordan stimulerer naturstien elevene i gå-etappene?

4) I hvilken grad må elevene samarbeide i naturstien?

5) I hvilken grad er oppgavene aktiviserende for elevene?

6) I hvilken grad blir elevene følelsesmessig tilknyttet til oppgavene?

7) I hvilken grad er det variasjon mellom postene?

Spørsmål 1: Hvordan er postens naturfaglige innhold knyttet til omgivelsene?

Designet av naturstien styres til dels av hvor i naturen fenomenene som skal undersøkes befinner seg (Foster, 1989; Spangler, 2004), samt hvor eksisterende stier er lagt i terrenget. Ved at oppgavene og kunnskapsinnholdet er kontekstnære og knyttet til fenomenene som skal utforskes vil det gi større mening for elevene å gå naturstien. I denne naturstien kunne for eksempel Post 3 dreid seg om utbygging av kjernekraftverk på akkurat denne plassen posten er plassert. Tanken om at det skal bygges kjernekraftverk, kan skape engasjement fordi elevene står overfor et dilemma i deres nærmiljø. Den samme klassen viste engasjement ved en lignende naturfaglig case i nærmiljøet (Iversen \& Jónsdóttir, 2018a). Andre eksempler på aktiviteter elevene kan gjøre er enkelte målinger med geigerteller ved granittforekomster, slik som Foster (1989) foreslår. På sistnevnte måte vil nærmiljøet bli benyttet selv ved en mindre åpen oppgave. Samtidig bør postenes plassering sees i sammenheng med eksisterende sti med tanke på utfordringer knyttet til navigering.

Spørsmål 2: Hvordan bindes oppgavene i postene til et for- og etterarbeid?

Gjennomføringen viser at kun post 3 tar hensyn til et for- og etterarbeid. At elevene møter et faglig innhold de har noe kjennskap til og at naturstien bidrar med noe som blir brukt i et etterarbeid kan tydeliggjøre hvorfor undervisningen foregår utendørs. I tillegg viser litteratur at en kobling mellom uteundervisning og etterarbeidet styrker elevenes faglige læring (Remmen \& Frøyland, 2015). De mer kognitive læringsaspektene vil trolig derfor øves med slik kobling. I naturstien var det tydelig at begreper som blir benyttet i postene, slik som for eksempel halveringstid, bør være presentert på forhånd (eller ev. forklares kort i posten) for ikke å skape frustrasjon. Elevene bør også få informasjon om at noe de gjør i naturstien, som for eksempel å lage en video, skal brukes i etterarbeidet.

Spørsmål 3: Hvordan stimulerer naturstien elevene i gå-etappene?

Halve tiden i naturstien ble brukt til å gå, og dette kan anses som ubrukt potensial for læring i en natursti. Gå-etappene kan bidra til at elevene øver sosiale aspekter ved at de sammen løser utfordringen om å orientere seg i landskapet. Gå-etappene kan også knyttes til oppgavene på post. For eksempel kan elevene få oppgaver som kan styrke relasjonene i gruppa, som å skape et gruppenavn. Det kan også være andre oppgaver slik som at elevene forteller hverandre om tre ting som de forbinder med det naturfaglige temaet. Elevene gikk på rekke hver gang stien smalnet. Dette kan gjøre det vanskelig for dem å prate sammen deler av stien. Oppgavene de får kan derfor også være individuelle, ved for 
eksempel at de enkeltvis samler inn materiale underveis, eller at de øver metakognitive aspekter, slik som hva de tenker om læring i uterommet.

Spørsmål 4: I hvilken grad må elevene samarbeide i naturstien?

Samarbeid om å løse oppgavene, navigering og orientere seg ute bør være en viktig del av naturstien. I denne naturstien samarbeidet elevene noe, spesielt om navigering, dog var det flere indikasjoner på at det var utfordringer i samarbeidet. Elevene kan øve sosiale aspekter både på postene og i gå-etappene ved at enkelte av oppgavene er formulert slik at elevene må samarbeide for å løse dem.

Spørsmål 5: I hvilken grad er oppgavene aktiviserende for elevene?

Oppgavene på postene kan tilrettelegge for utprøving, utforsking og registreringer for å aktivisere elevene. På denne måten kan elevene øve sosiale, fysiske- og ferdighetsmessige aspekter i tillegg til kognitive aspekter. Samtidig viste elevenes erfaringer fra post 3 at ved et mer åpent spørsmål, vil trolig elevene ha behov for mer støtte til å løse oppgaven.

Spørsmål 6: I hvilken grad blir elevene følelsesmessig tilknyttet oppgavene?

Når elevene arbeider med radioaktivitet og stråling er det gjerne knyttet til at noe er farlig. I tre av de fire postene finnes ord som 'ulykke' og 'farligst'; som spiller på de affektive aspektene av elevenes læring. Alsop og Watts (2000) undersøker affektive aspekter i undervisning av stråling og radioaktivitet. Å vektlegge følelsesmessige aspekter kan være nyttig, men bør benyttes med omhu for å ikke skape frykt. Videre argumenterer Alsop og Watts (2000) for at når eleven står overfor valg, er de affektive og kognitive aspektene tett knyttet sammen på en virkningsfull måte. Forslaget over om at elevene skal vurdere om det skal bygges kjernekraftverk i nærmiljøet, bidrar til at elevene står overfor et slikt valg, som kan være nyttig for læring av radioaktivitet og stråling.

Spørsmål 7: I hvilken grad er det variasjon mellom postene?

Til slutt vil det være nødvendig å vurdere naturstien som helhet. Det bør for eksempel være variasjon innad i postene med tanke på frihet, i tråd med Kisiels (2003) anbefalinger til utforming av arbeidsark. Det kan således være en fordel at det er en variasjon for eksempel på frihetsgrader, informasjonskilde og svarets format.

Ved et design av en natursti i naturfag vil disse syv spørsmålene og Kisiels (2003) punkter om utforming av arbeidsark, være et nyttig utgangspunkt for hvordan natursti kan tilrettelegge for målrettede erfaringer i naturfag.

\section{AVSLUTNING}

Å arbeide med praksisnær forskning gjør at DBR-forskere må ta hensyn til og blir påvirket av skolens virkelighet. Collins og kolleger $(2004,19)$ påpeker at DBR 'have some fundamental limitations. Because they are carried out in messy situations of actual learning environments (...) there are many variables that affect the success of the design, and many of these variables cannot be controlled.'

Naturstien speiler virkeligheten på flere måter. For eksempel er klasserommets tradisjoner i naturfagene godt synlig i naturstien. Stort sett alle oppgavene i naturstien synes å bære preg av en mer lærerstyrt spørsmål-svar praksis. Dette er i tråd med litteratur som har kartlagt at undervisningen tilknyttet naturfag (Ødegaard \& Arnesen, 2010) og fysikk (Duit m.fl., 2014) ofte er sentrert rundt lærer. En norsk studie viste at naturfagundervisningen i stor grad dreier seg rundt spørsmål fra lærer og enkeltsvar fra elevene, eller at elevene svarte på oppgaver fra boka (Ødegaard \& Arnesen, 2010). I en studie fra en vitensenterkontekst, fant Stuedahl (2017) at formidlernes pedagogiske kunnskap var sterkt tilknyttet skolen. Formidlerne hadde i mindre grad forståelse rundt selvstyrt læring i åpne utstillingsrom med en mer kroppslig læringsopplevelse (Stuedahl, 2017). Lærernes perspektiver på læring ved implementering av uteundervisning gjennom design har tidligere blitt utforsket (Iversen \& Jónsdóttir, 2018b). Iversen og Jónsdóttir (2018b) viser at det er utfordringer knyttet til løsrivelse fra tradisjonene i naturfagklasserommet. 
Et lignende sentralt punkt er at da denne naturstien skulle gjennomføres, var stråling og radioaktivitet temaet på årsplanen for dette trinnet. Radioaktiv stråling, som var hovedfokuset i dette opplegget, omgir mennesker hver dag, men det er vanskelig å sanse av mennesker uten bruk av redskaper som geigerteller. Derfor kan det stilles spørsmål ved om naturen kan være en autentisk og kontekstuell læringsarena i dette temaet. Som Elsa og Jannike påpekte tidligere, ville elevene kanskje ha opplevd det mer hensiktsmessig å ha et tema som var nærmere knyttet til biologi. Ifølge Ayotte-Beaudet m. fl. (2017) er det økologi som er det hyppigste temaet som undervises ute. Post 4 er et forøk på å overlappe økologi og radioaktivitet. Dog er denne posten tilknyttet alpint økosystem og ikke økosystem i lavlandet i Norge. Dermed blir heller ikke Post 4 knyttet til omgivelsene. Likevel bør det ikke ses bort fra at elevene kan få gode erfaringer i temaet så fremt elevene får nok støtte i å gjøre koblinger til virkeligheten.

Artikkelens begrensninger er i hovedsak knyttet til to ting.

(i) Datamaterialet er begrenset til spesielt én gruppes erfaringer. Ved å få innsyn i flere gruppers gjennomføring ville det kunne bidratt til å nyansere funnene, slik som da vår gruppe møtte Jakob og Daniel sin gruppe.

(ii) Redesign, med utgangspunkt i de syv didaktiske spørsmålene, har ikke blitt videre prøvd ut i praksis.

En av artikkelens viktigste bidrag er å synliggjøre natursti som en uteundervisningsmetode i naturfag. Natursti er, som nevnt, et tilsynelatende lite utforsket område innenfor uteundervisning i naturfag. Denne artikkelen møter også Ayotte-Beaudet og kollegenes (2017) kall etter mer forskning om uteundervisning i temaer tilknyttet fysikk. De syv didaktiske spørsmålene og artikkelens analyseverktøy kan benyttes til å utforme og vurdere kvaliteten av eksisterende naturstier. Til slutt kan artikkelen være et utgangspunkt for andre som vil undersøke bruk av natursti som uteundervisningsmetode.

\section{REFERANSER}

Alsop, S. \& Watts, M. (2000). Facts and feelings: exploring the affective domain in the learning of physics. Physics Education, 35(2), 132-138. doi:10.1088/0031-9120/35/2/311

Anderson, T. \& Shattuck, J. (2012). Design-based research: A decade of progress in educational research. Educational Researcher, 41(1), 16-25. doi:10.3102/0013189X11428813

Aspinall, C. (2016). Using outdoor adventure settings to teach physics. School Science Review. 98, $110-114$.

Ayotte-Beaudet, J-P., Potvin, P., Lapierre, H.G., \& Glackin, M. (2017). Teaching and learning science outdoors in schools' immediate surroundings at K-12 levels: A meta-synthesis. Journal of Mathematics Science and Technology Education, 13(8): 5343-5363. doi:10.12973/ eurasia.2017.00833a

Barab, S. \& Squire, K. (2004). Design-based research: Putting a stake in the ground. The Journal of the Learning Sciences, 13(1), 1-14. doi: 10.1207/s15327809jls1301_1

Braund, M., \& Reiss, M. (2006). Towards a more authentic science curriculum: The contribution of out-of-school learning. International Journal of Science Education. 28(12), 1373-1388. doi:10.1080/09500690500498419

Design-Based Research Collective, (2003). Design-based research: An emerging paradigm for educational inquiry. Educational Researcher, 5-8. doi:10.3102/0013189X032001005

Collins, A., Joseph, D., \& Bielaczyc, K. (2004). Design research: Theoretical and methodological issues. Journal of the Learning Sciences. 13(1), 15-42. doi:10.1207/s15327809jls1301_2

Dewey, J. (1938/1991). Experience and Education. New York: Simon \& Shuster. doi: 10.1080/00131728609335764

Dhanapal, S., \& Lim, C.C.Y. (2013). A comparative study of the impacts and students' perceptions of indoor and outdoor learning in the science classroom. Asia-Pacific Forum on Science Learning and Teaching, 14(2), 1-23. 
Duit, R., Schecker, H., Höttecke, D. \& Niedderer, H. (2014). Teaching physics. I N.G. Lederman \& S.K. Abell (Red.). Handbook of research in science education (434-456). New York, NY: Routledge.

DeWitt, J., \& Storksdieck, M. (2015). Excursions. I R. Gunstone (Red.) Encyclopedia of Science Education. (415-418). London: Springer. doi:10.1007/978-94-007-6165-0_292-2

Fägerstam, E. (2014). High school teachers' experience of the educational potential of outdoor teaching and learning. Journal of Adventure Education and Outdoor Learning, 14(1), 56-81. doi:10.1080/14729679.2013.769887

Fägerstam, E., \& Blom, J. (2013). Learning biology and mathematics outdoors: effects and attitudes in a Swedish high school context. Journal of Adventure Education \& Outdoor Learning, 13(1), 56-75. doi:10.1080/14729679.2011.647432.

Foster, S. (1989). Streetwise physics. School Science Review, 7o(254), 15-17.

Frøyland, M., Remmen, K. B., Mork, S. M., Ødegaard, M., \& Christiansen, T. (2015). Researching features of science learning from students' view-the potential of headcam. NorDiNa, 11(3), 249-267.

Glackin, M. (2016). 'Risky fun' or 'Authentic science'? How teachers' beliefs influence their practice during a professional development programme on outdoor learning. International Journal of Science Education, 38(3), 409-433. doi:10.1080/09500693.2016.1145368

Iversen, E. \& Jónsdóttir, G. (2018a). "We did see the lapwing" - Practising environmental citizenship in upper-secondary science education. Environmental Education Research, 25(3), 411-421. doi:10.1080/13504622.2018.1455075

Iversen, E. \& Jónsdóttir, G. (2018b). A bit more than a fly on the wall: Roles and responsibilities in Design-based research. Designs for learning, 10(1), 18-28. doi: 10.16993/dfl.79

Juuti, K. \& Lavonen, J. (2006). Design-based research in science education: One step towards methodology. NorDiNa, 4, 54-68. doi: 10.5617/nordina.424

Kent, M., Gilbertson, D.D., \& Hunt C.O. (1997). Fieldwork in geography teaching: a critical review of the literature and approaches. Journal of Geography in Higher Education, 21(3), 313-332. doi:10.1080/03098269708725439

Kerry, T. (1979). Hartsholme: A model for devising and using a nature trail. Journal of Biology Education. 13(1), 32-40. doi:10.1080/00219266.1979.9654224

Kisiel, J. (2003). Teachers, museums and worksheets: A closer look the learning experience. Journal of Science Teacher Education, 14, 3-21. doi: 10.1023/A:1022991222494

Lehto, K., Lehto, H.J., Brozinski, A., Gardner, E., Eklund, O., Rajala, K., Räsänen, M., Sääksjärvi, I., Vainio, L., \& Vuorisalo, T. (2012). Time Trek: a 13.7km long nature trail leading through the history of the Universe and the Earth. International Journal of Astrobiology. 1-7. doi:10.1017/ S1473550412000225.

Mogk, D.W. \& Goodwin, C. (2012). Learning in the field: Synthesis of research on thinking and learning in the geosciences. Geological Society of America Special Papers. 486, 131-163. doi:10.1130/2012.2486(24)

Mortensen, M.F. \& Smart, K. (2007). Free-choice worksheets increase students' exposure to curriculum during museum visits. Journal of Research in Science Teaching, 44(9), 1389-1414. doi:10.1002/tea.20206

Myers, F.R. (1930). A nature trail at Bernards high school. School Science and Mathematics, 3o(6), 668-670. doi: 10.1111/j.1949-8594.1930.tbo2756.x

Myers, F.R. (1934). More nature trails: A project in out-door biology. School Science and Mathematics, 34(7), 733-737.

Orion, N., \& Hofstein, A. (1994). Factors that influence learning during a scientific field trip in a natural environment. Journal of Research in Science Teaching, 31, 1097-1119. doi:10.1002/ tea.3660311005

Pendrill, A-M. (2013). Student investigation of the forces in a roller coaster loop. European Journal of Physics, 34(6), 1379-1389. doi:10.1088/0143-0807/34/6/1379 
Plomp, T. (2013). Educational design research: An introduction. I T. Plomp \& N. Nieveen (Red.). Educational design research: Part A. (10-51). Nederland: SLO.

Popov, O. (2006). Developing outdoor activities and a website as resources to stimulate learning physics in teacher education. Journal of Physics Teacher Education Online, 3(3), 18-24.

Reeves, T. C., Herrington, J., \& Oliver, R. (2005). Design research: A socially responsible approach to instructional technology research in higher education. Journal of Computing in Higher Education, 16(2), 96-115. doi:10.1007/bfo2961476

Remmen, K.B., \& Frøyland, M. (2014). Implementation of guidelines for effective fieldwork designs: exploring learning activities, learning processes, and student engagement in the classroom and the field. International Research in Geographical and Environment Education, 23(2), 103-125. doi: 10.1080/10382046.2014.891424

Remmen, K.B., \& Frøyland, M. (2015). What happens in classrooms after earth science fieldwork? Supporting students learning process during follow-up activities. International Research in Geographical and Environment Education, 24(1), 24-42. doi:10.1080/10382046.2014.967114

Rickinson, M., Dillon, J., Teamey, K., Morris, M., Ckoi, M. Y., Sanders, D. \& Benefield, P. (2004). A review of research on outdoor learning. Preston Montford, Shorpshire: Field Study Council.

Stuedahl, D. (2017). Aksjonsforskning i norske vitensentre: Re-design og utvikling av pedagogisk praksis i vitensentre. I S. Gjøtterud, H. Hiim, D. Husebø, L.H. Jensen, T.H. Steen-Olsen, \& E. Stjernstrøm, (Red.). Aksjonsforskning i Norge: teoretisk og empirisk mangfold. (379-397). Cappelen Damm Akademisk.

Spangler, L. (2004). P.H.Y.S.I.C.S. can be done! Science and Children. 41(6), 30-33.

Tiberghien, A., \& Sensevy, G. (2012). The Nature of Video Studies in Science Education. I D. Jorde \& J. Dillon (Red.) Science Education Research and Practice in Europe. Retrospective and prospective (141-179). Sense Publishers. doi:10.1007/978-94-6091-900-8_7

Wang, F., \& Hannafin, M. J. (2005). Design-based research and technology-enhanced learning environments. Educational Technology Research and Development, 53(4), 5-23. doi:10.1007/ BFo2504682

Wilhelmsson, B., Ottander, C. \& Lidestav, G. (2012). Teachers' intentions with outdoor teaching in school forests: Skills and knowledge teachers want students to develop. NorDiNa, 8(1): 26-42. doi:10.5617/nordina.357

Ødegaard, M., \& Arnesen, N. (2010). Hva skjer i naturfagklasserommet? Resultater fra en videobasert klasseromsstudie; PISA+. NorDiNa, 6(1), 16-32. doi:10.5617/nordina.271

Öhman, J., \& Sandell, K. (2016). Environmental concerns and outdoor studies: Nature as fosterer. I B. Humberstone, H. Prince, \& K.A. Henderson (Red.), Routledge international handbook of outdoor studies. London: Routledge. 